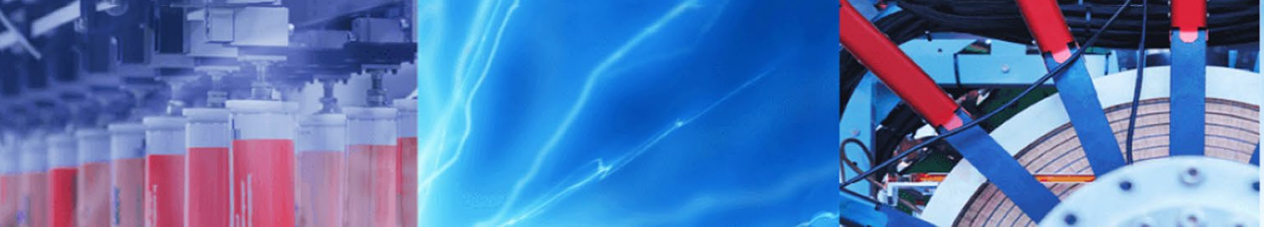

Research Article

\title{
Semi-vitrified porous kyanite mullite ceramics: Young modulus, microstructure and pore size evolution
}

\author{
Juvenal N. G. Deutou ${ }^{1,2,3}$ (D) Ntieche Zounedou ${ }^{1} \cdot$ Rodrigue C. Kaze $^{5} \cdot$ Hawa Mohamed $^{1} \cdot$ Tibi Beda $^{2} \cdot$ U. C. Melo ${ }^{2}$. \\ Elie Kamseu $^{1,4} \cdot$ Vincenzo M. Sglavo $^{3}$
}

Received: 27 September 2019 / Accepted: 11 December 2019 / Published online: 21 December 2019

(c) Springer Nature Switzerland AG 2019

\begin{abstract}
Microporous porcelain formulations are successfully carried out through sintering processing. During the thermal treatment of ceramic products, it was found that the addition of kyanite together with $\phi$ - and $\gamma-\mathrm{Al}_{2} \mathrm{O}_{3}$ allowed to enhance interconnected pores network with micrometric size from 0.1 to $9 \mu \mathrm{m}$ in a semi-vitrified composite. Between 1200 and $1350^{\circ} \mathrm{C}$, the mullitization of kyanite hindered the extension of vitrification and the growth of acicular mullite from the transformation of metakaolin. The main pores size decreased from 4.33 to $1.54 \mu \mathrm{m}$ for the formulation containing $32 \mathrm{wt} \%$ of kyanite. In this interval the specific pore area increased from 0.64 to $8.75 \mathrm{~m}^{2} \mathrm{~g}^{-1}$ due to the total conversion of the kyanite to fibrous and acicular mullite that reduced the voids provided by the earlier mullitization. The improvement in the mullitization without extensive vitrification and grain growth and the reduction of the pores size with the increase in the specific pore area contributed to the formation of a microporous matrix with the Young's modulus increased from 7 to $>20 \mathrm{GPa}$. The microstructure of the microporous porcelain, their specific pore area and pores size as well as the interconnection of pores was found innovative for the applications in the field of engineering filtration where high mechanical strength, strain, stiffness and pressure resistance are required.
\end{abstract}

Keywords Microporous porcelain $\cdot$ Kyanite $\cdot$ Interconnected pores $\cdot$ Microstructure $\cdot$ Elastic modulus

\section{Introduction}

Porcelain materials are characterized by important technological features like high mechanical and chemical stability, high hardness, wear resistance and durability [1-3]. Therefore, porous porcelain matrices can be recommended and promising for filtering applications (hot gas filters, heat exchangers for turbine engines and gas separators) [4-6]. Their final microstructure is controlled by the amount of glassy phase formed upon vitrification, porcelain being densified by viscous flow sintering mechanisms, and in particular, the viscosity of the liquid/glassy phase affects the pore network. Porous porcelain used for filtering applications like catalyst supports, hot gases filter, liquid food productions, membrane reactors and heat exchangers for turbines should possess limited glassy phase [4-7]. It is also important to control the amount and consistency of the glassy phase produced upon sintering to guarantee the presence of the fine well-interconnected pores network. In a previous work [8], the presence of interconnected pores with the size between $3 \mathrm{~nm}$ and $4.5 \mu \mathrm{m}$ was achieved by producing a glassy phase with low thermal expansion coefficient starting from kaolin, bauxite, feldspar and kyanite [8]. It was shown that the

\footnotetext{
$\triangle$ Juvenal N. G. Deutou, giogetti@live.fr; $\square$ Elie Kamseu, kamseuelie2001@yahoo.fr|' Local Materials Promotion Authority (MIPROMALO), P.O. Box 2396, Yaoundé, Cameroon. ${ }^{2}$ Department of Physics, University of Ngaoundéré, P.O. Box 454, Ngaoundéré, Cameroon. ${ }^{3}$ Department of Industrial Engineering, University of Trento, Via Sommarive, 938123 Trento, Italy. ${ }^{4}$ Dipartimento di Ingegneria dei Materiali e dell'Ambiente, Università di Modena e Reggio Emilia, Via Vignolese 905, 41100 Modena, Italy. ${ }^{5}$ Laboratory of Applied Inorganic Chemistry, Faculty of Science, University of Yaoundé I, P.O. Box 812, Yaoundé, Cameroon.
} 
presence of kyanite delayed the vitrification at relatively low temperature and improved the formation of mullite at high temperature, thus allowing the maintenance of certain porosity in a mechanically stable matrix. In order to understand the properties of this type of porous semi-vitrified matrices, it is necessary to investigate their formation mechanisms. Firstly, the difference exists between the vitrification range of the feldspar and the decomposition of kyanite in the mullite appeared. Kyanite as starting materials is a mixture of an alumina-rich and silica-rich material with the molar ratio of $\mathrm{Al}_{2} \mathrm{O}_{3} / \mathrm{SiO}_{2}=1$. In addition, the sillimanite group minerals include kyanite, sillimanite and andalusite, all of which can be represented by the chemical formula $\mathrm{Al}_{2} \mathrm{O}_{3} \cdot \mathrm{SiO}_{2}$, which corresponds to the content $62.9 \% \mathrm{Al}_{2} \mathrm{O}_{3}$ and $37.1 \% \mathrm{SiO}_{2}$. There is, however, a marked difference in their crystal structures and properties. Above $1250{ }^{\circ} \mathrm{C}$, kyanite is converted to mullite $\left(3 \mathrm{Al}_{2} \mathrm{O}_{3} \cdot \mathrm{SiO}_{2}\right)$ and free silica $\left(\mathrm{SiO}_{2}\right)$, and $\mathrm{SiO}_{2}$ provides the structure of the viscoelastic toughening $[9,10] . \mathrm{K}_{2} \mathrm{O}, \mathrm{Na}_{2} \mathrm{O}$ and $\mathrm{CaO}$ oxides of natural kyanite were known to alter the viscosity and the glass transition temperature of silicates. At lower temperature in the aluminosilicates refractory, $\mathrm{K}_{2} \mathrm{O}, \mathrm{Na}_{2} \mathrm{O}$ and $\mathrm{CaO}$ promote the formation of viscous glassy phase and strengthen the viscous ligaments formed [10]. Kyanite crystallizes in triclinic system and starts decomposition only at temperature $>1100^{\circ} \mathrm{C}$. With the presence of both free silica and reactive $\mathrm{Al}_{2} \mathrm{O}_{3}$ at high temperature, the formation of the acicular mullite is favored through atomic diffusion [11-13]. Additionally, the microstructural evolution of the kyanite during sintering is particular with the development of fibrous and acicular mullite between 1200 and $1350^{\circ} \mathrm{C}$ far from the large size and elongated secondary mullite developed in the semi-vitrified matrix of porcelain considering the same range of temperature [14-17]. During the process of the decomposition of the kyanite particle, multitude mode of pores appeared in the matrices. Highly reactive alumina (a-alumina) derived from the calcined bauxite [18-20] contributes to the secondary mullite formation with the ceramic linkages developed; this enhances the apparent porosity by consuming the glassy silica. Thus, the secondary mullitization limited the formation of the excess of liquid phase.

The present work deals with the understanding of the mechanism formation of porous semi-vitrified matrices. This includes the descriptive microstructure and the pore size development. The works successfully demonstrated the ability of the kyanite particles to control the mullitization process and hinder the feldspar vitrification during the sintering processing. Therefore, it describes in detail the pore volume, pore size behavior and their interconnection within the matrices, giving information regarding the changes that appear following the action of kyanite at low and high temperature. The viscoelastic phase developed, mullitization and the simultaneous pore network forming with consequent changes in the elastic behavior of the porous matrices are discussed using microstructural approach.

\section{Experimental procedures}

\subsection{Preparation of the samples}

Metakaolin, calcined bauxite, feldspar and kyanite were used as raw materials in the present work. Their chemical composition is reported in Table 1. Metakaolin was prepared by calcination of a standard kaolin collected from Mayouom, Cameroon. Bauxite was obtained from the Danielle Bauxite Plains of the Tchabal-Haleo Sector in Mini Martap, a neighborhood in the Adamawa Region, Cameroon. Bauxite was calcined at $700^{\circ} \mathrm{C}$ for $4 \mathrm{~h}$ (heating rate $=5^{\circ} \mathrm{C} / \mathrm{min}$ ). Kyanite was collected from Makak in the Centre Region of Cameroon. Feldspar was obtained from Linté-Ngambé Tikar, a neighborhood in the Centre Region, Cameroon. Before mixing, each material was ball milled in a porcelain jar to achieve a particles size below $67 \mu \mathrm{m}$. Three formulations were considered as shown in Table 2.

All the ingredients were mixed, wet and ball milled for $60 \mathrm{~min}$ in rapid ball mill at $1200 \mathrm{rpm}$. The obtained paste was dried at room temperature down to $10-15 \%$ water.

Table 2 Chemical composition of the three formulations

\begin{tabular}{lllll}
\hline & Kyanite (wt\%) & $\begin{array}{l}\text { Metakaolin } \\
(w t \%)\end{array}$ & $\begin{array}{l}\text { Calcined baux- } \\
\text { ite (wt\%) }\end{array}$ & $\begin{array}{l}\text { Feld- } \\
\text { spar } \\
(w t \%)\end{array}$ \\
\hline PK3 & 28 & 32 & 15 & 25 \\
PK4 & 32 & 28 & 15 & 25 \\
PK5 & 37 & 23 & 15 & 25 \\
\hline
\end{tabular}

Table 1 Chemical composition of the used raw materials (metakaolin, calcined bauxite, kyanite and feldspar)

\begin{tabular}{lcrlllllll}
\hline & $\mathrm{Al}_{2} \mathrm{O}_{3}$ & $\mathrm{SiO}_{2}$ & $\mathrm{TiO}_{2}$ & $\mathrm{Fe}_{2} \mathrm{O}_{3}$ & $\mathrm{CaO}$ & $\mathrm{K}_{2} \mathrm{O}$ & $\mathrm{NaO}_{2}$ & $\mathrm{MgO}$ & $\mathrm{LOI}$ \\
\hline Metakaolin & 39.4 & 51.6 & 5.1 & 1.9 & - & 0.9 & - & - & 1.1 \\
Calcined bauxite & 91.2 & 0.7 & 5.4 & 2.1 & - & - & - & - & 0.6 \\
Kyanite & 59.4 & 36.9 & - & 3.0 & - & - & - & - & 0.7 \\
Feldspar & 17.8 & 68.1 & - & 0.4 & 0.2 & 11.4 & 2.0 & 0.1 & 0.1 \\
\hline
\end{tabular}


Cylindrical pellets (diameter $=50 \mathrm{~mm}$, thickness $=4-6 \mathrm{~mm}$ ) were prepared by uniaxial pressing using a maximum pressure of $40 \mathrm{MPa}$. The specimens were dried at $105^{\circ} \mathrm{C}$ for $24 \mathrm{~h}$ before firing. This was carried out in an electric furnace (Borel FP 1600, Standard Furnaces \& Ovens) at 1200, 1275,1350 and $1400^{\circ} \mathrm{C}$ for $1 \mathrm{~h}$ using a heating rate of $5^{\circ} \mathrm{C} /$ $\mathrm{min}$. The samples were then cooled down naturally in the furnace.

\subsection{Characterization of fired specimens}

The pores volume and pores size distribution were determined using a mercury intrusion porosimeter (MIP, Carlo Erba 2000) equipped with a macropores unit (Pascal 140, Fisons Instruments) which allows the application of a maximum pressure of 2000 bar. Samples of about $\sim 1 \mathrm{~cm}^{3}$ were dried in vacuum before testing. The pores size was calculated through the Washburn equation [21, 22]:

$D=-\frac{4 \gamma}{P} \cos \emptyset$

where $P$ is applied pressure, $\emptyset$ the contact angle of mercury $\left(141.3^{\circ}\right) D$ and $\gamma$ the surface tension of mercury (480 dyne/ $\mathrm{cm})$.

The biaxial flexural strength of the fired samples was measured by the piston-on-three balls method. The test was carried out according to ASTM standard C1161 [20, 23].

The microstructure of the fired samples was analyzed by SEM (JEOL-JSM5500). Microchemical analyses were carried out with the same instrument fitted with an energydispersive X-ray detector (EDS, Joel IT300). The samples were mounted on aluminum stubs and sputter coated with $\mathrm{Pt} / \mathrm{Pd}$; some of them were preliminarily etched in $5 \%$ $\mathrm{HF}-\mathrm{HNO} 3$ water solution for $30 \mathrm{~s}$ to reveal the crystalline phases better.

\section{Results and discussion}

\subsection{Formation of highly viscoelastic phase}

The formulation of porcelain using kyanite instead of quartz conducts the formation of more viscous liquid phase during sintering, and the reduction of the extension of the fluidity of the vitrified phase is responsible for the porous final microstructure obtained (Figs. 1 and 2). In fact, the use of kyanite reduced the silica available in the matrix after the formation of primary mullite. Consequently, reduction of the extension of the formation of vitreous phase is more limited with the presence of calcined bauxite $\left(\rho-\mathrm{Al}_{2} \mathrm{O}_{3}\right.$ or $\left.\mathrm{a}-\mathrm{Al}_{2} \mathrm{O}_{3}\right)$, most reactive form of alumina [9] ready to bind with the amorphous (reactive) silica available. At $1200^{\circ} \mathrm{C}$, the amount of kyanite in each formulation affected the amount of viscoelastic phase formed and the final microstructure (Fig. 1). Increasing the kyanite content, the cumulative pores volume increased as the consequence of the reduction of the viscosity of glassy phase formed. At this stage, the decomposition of kyanite has begun. Alkalis oxides present in the raw kyanite such as $\mathrm{Na}_{2} \mathrm{O}$ and $\mathrm{K}_{2} \mathrm{O}$ acted to affect the viscoelastic phase. Together with the presence of $\mathrm{Fe}_{2} \mathrm{O}_{3}$, the viscous phase formation insured the densification of the inter-pores spaces and seemed to play a key role for the strengthening mechanism of the porous semi-vitrified products. Indeed, the densified inter-pores spaces favoured the stability of the matrices. This could be result in high resistances development by those matrices although the important pores network formation.

When the temperature increased between 1200 and $1400{ }^{\circ} \mathrm{C}$, there coexists in the system the decomposition of the kyanite with the formation of mullite and glassy viscous phase from the feldspar-metakaolin mix where the mullitization started earlier. In standard porcelain formulations, at that stage, it is expected shrinkage which here is compensated with the expansion linked to the expansive action of silica from kyanite decomposition. The combined action of glassy phase and alumina from calcined bauxite, in the matrices, enhances the formulation of secondary mullite (Fig. $2 \mathrm{a}-\mathrm{C}$ ) and the reduction of the extension of the formation and expression of glassy phase is demonstrated in the next paragraph. The expansion contributed to maintain the porosity inducing low sinter ability and low densification. Moreover, there were no microcracks observed in the matrices as it is the case with conventional triaxial porcelain as from the thermal coefficient expansion mismatch. In the latter the extension of liquid phase makes a gap between the thermal expansion coefficient of liquid phase and the crystalline more important particularly when quartz particles are concerned [1, 2, 24, 25].

The expression of the glassy phase decreased with the temperature and the kyanite content (Figs. 1 and 2). This is completely different from the general behavior of the porcelain and semi-vitrified ceramic systems [26-28]. The principal explanation is the presence of low-temperature formation of alumina ( $\rho$ - or $a-\mathrm{Al}_{2} \mathrm{O}_{3}$ ) that will still in the matrix and reacts subsequently with the reactive $\mathrm{SiO}_{2}$ from the decomposition of kyanite that is continued between 1100 and $1300{ }^{\circ} \mathrm{C}$. Amorphous silica is not transformed into liquid phase but reacts to form mullite. The extension of the formation of viscous phase at low temperature $\left(1200-1275^{\circ} \mathrm{C}\right)$ compared to high temperature is from the low eutectic $\left(\sim 950^{\circ} \mathrm{C}\right)$ that characterizes the $\mathrm{K}_{2} \mathrm{O}-\mathrm{Al}_{2} \mathrm{O}_{3}-\mathrm{SiO}_{2}$ systems. However, the simultaneous 

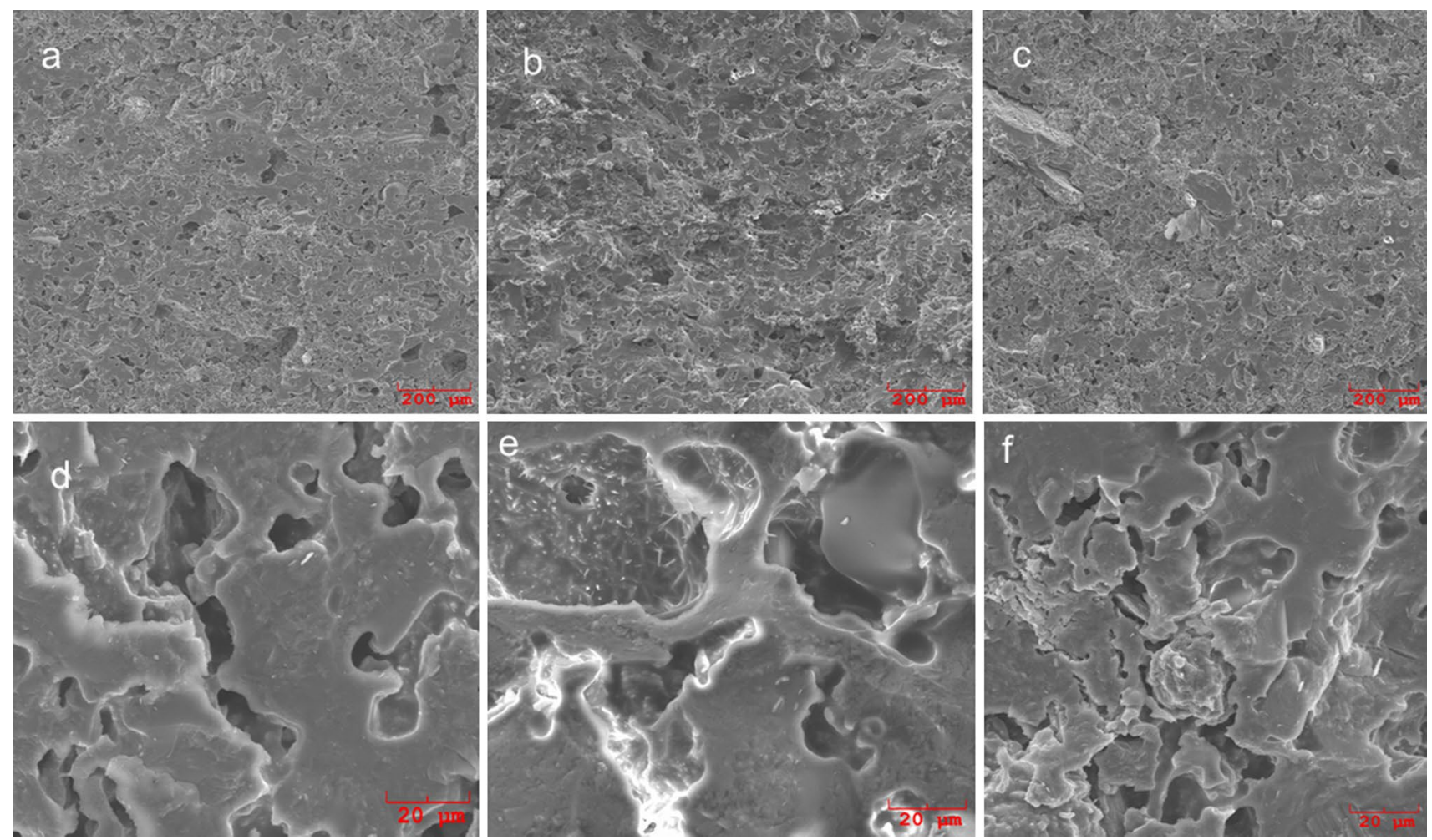

Fig. 1 Micrograph of porous mullite matrix composites sintered at $1200^{\circ} \mathrm{C}: \mathbf{a}, \mathbf{d} \mathrm{PK} 3, \mathbf{b}, \mathbf{e} \mathrm{PK} 4$ and $\mathbf{c}, \mathbf{f} \mathrm{PK} 5$

presence of reactive $\mathrm{Al}_{2} \mathrm{O}_{3}$ and $\mathrm{SiO}_{2}$ contributed to hinder the vitrified phase.

\subsection{Mullitization}

The mechanism of the mullitization (from the aluminosilicates) occurring during the sintering process within the matrices can be described. The first thermochemical transformation that takes place in the metakaolin-kyanitecalcined bauxite-K-feldspar is the transformation of the metakaolin to acicular mullite (or primary mullite) following Eq. (2):

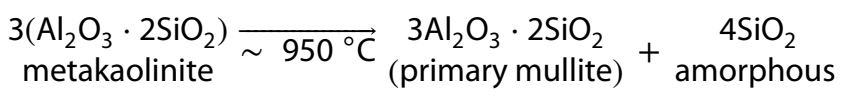

It is expected that the residual $\mathrm{SiO}_{2}$ from the transformation of metakaolin to the primary mullite combines $\mathrm{Al}_{2} \mathrm{O}_{3}$ of the calcined bauxite to form secondary mullite. However, in general the reaction depends on the form of $\mathrm{Al}_{2} \mathrm{O}_{3}$ present and may take place at relatively higher temperature. Guo and $\mathrm{Li}$ [9] show that when $\mathrm{Al}_{2} \mathrm{O}_{3}$ reacts with amorphous silica, the crystals type of the following allotropic forms $\mathrm{Al}(\mathrm{OH})_{3}, \mathrm{\gamma}-\mathrm{Al}_{2} \mathrm{O}_{3}, \rho-\mathrm{Al}_{2} \mathrm{O}_{3}$ and $\mathrm{a}-\mathrm{Al}_{2} \mathrm{O}_{3}$ reduces in respective order of the diffraction peak intensity of mullite, while that of corundum shows an opposite character. Since bauxite was calcined at $700^{\circ} \mathrm{C}$, it is possible to suggest the presence of $\mathrm{Y}^{-} \mathrm{Al}_{2} \mathrm{O}_{3}$ that can be obtained firing the $\mathrm{Al}(\mathrm{OH})_{3}$ at $500^{\circ} \mathrm{C}[29,30]$. Between 500 and $900{ }^{\circ} \mathrm{C}$ due to rapid cooling, $\rho-\mathrm{Al}_{2} \mathrm{O}_{3}$ can be obtained. With the presence of those crystals, it is possible that the reaction of Eq. (3) takes place even at a relatively low temperature:

$$
3 \mathrm{Al}_{2} \mathrm{O}_{3}+2 \mathrm{SiO}_{2} \text { (Amorphous) } \rightarrow \begin{gathered}
3 \mathrm{Al}_{2} \mathrm{O}_{3} \cdot 2 \mathrm{SiO}_{2} \\
\text { (secondary mullite) }
\end{gathered}
$$

Due to the amorphous nature of silica formed and the relatively low temperature of the calcination of bauxite $\left(700^{\circ} \mathrm{C}\right)$, reactions between both components could take place just after the formation of acicular mullite from metakaolin. This can explain that a part of the limited expression of the liquid phase instead generally follows the mullite formation in the porcelain matrices as from the presence of feldspar. The end of the transformation of metakaolin to acicular mullite corresponds with the beginning of the decomposition of kyanite to mullite and additional amorphous silica as indicated in Eq. (4): 

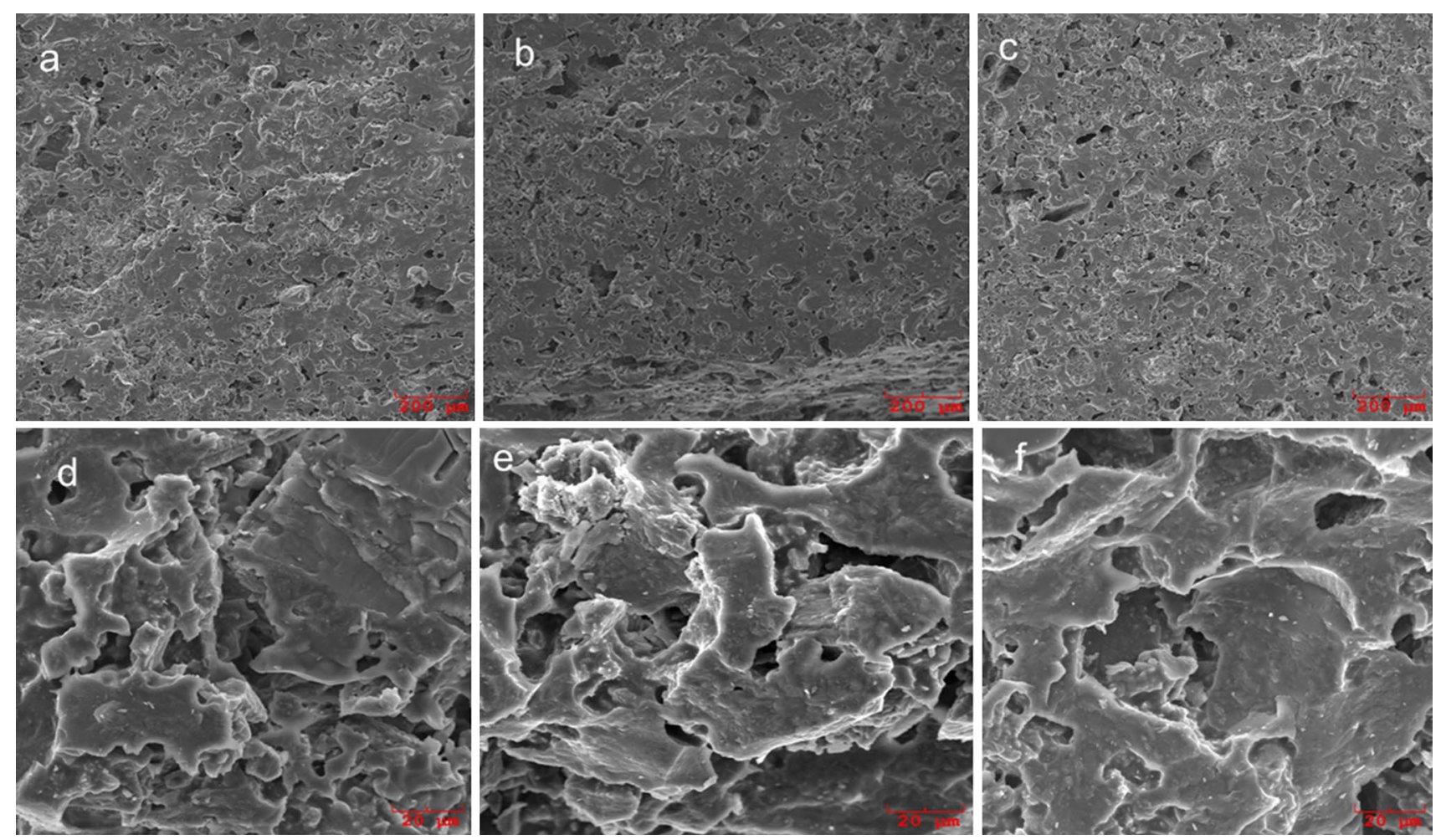

Fig. 2 Micrograph of porous mullite matrix composites sintered at $1400^{\circ} \mathrm{C}: \mathbf{a}, \mathbf{d}$ PK3, b, e PK4 and $\mathbf{c}$, f PK5

$$
\begin{aligned}
& 3\left(\mathrm{Al}_{2} \mathrm{O}_{3} \cdot \mathrm{SiO}_{2}\right) \underset{1100-1350{ }^{\circ} \mathrm{C}}{(\text { kyanite })} \\
& \begin{array}{l}
3 \mathrm{Al}_{2} \mathrm{O}_{3} \cdot 2 \mathrm{SiO}_{2} \\
\text { mullite amorphous silica }
\end{array}
\end{aligned}
$$

As it can be observed in Fig. 3, the peak of mullite with $2 \theta=16.39^{\circ}$ showed a significant increase in intensity between 1200 and 1275 and between 1275 and $1400{ }^{\circ} \mathrm{C}$. Results are in agreement with the findings of Sainz et al. [31]. Quartz grains were almost inexistent in the matrices particularly at high temperature. There was still some crystallization of cristobalite, confirming the idea that the described reaction sequences include the transformation of $\mathrm{Al}(\mathrm{OH})_{3}$ to $\mathrm{\gamma}-\mathrm{Al}_{2} \mathrm{O}_{3}, \rho-\mathrm{Al}_{2} \mathrm{O}_{3}$ and a- $\mathrm{Al}_{2} \mathrm{O}_{3}$, while metakaolin was transforming to acicular mullite, and the decomposition of kyanite to mullite and the reaction between alumina and silica are not always $100 \%$ successful reactions. Glassy phase, quartz, cristobalite and corundum are then considered as minor phases of the porous mullite matrices.

\subsection{Pores size distribution and their interconnection}

Figure 4 and Table 3 detail the pore size distribution and the average pore radius of the porous ceramic matrix (PK3, PK4 and PK5) sintered between $1200^{\circ} \mathrm{C}$ and $1400^{\circ} \mathrm{C}$. The general observations regarding the porosity of the kyanite-based porous mullite composites were linked to the increase in the volume of pores with the rise of the kyanite content up to $1275^{\circ} \mathrm{C}$ [8]. This corresponds to a multimodal pore size distribution with the average pore size that increases from 3.22 to $3.25 \mu \mathrm{m}$ between 1200 and $1275^{\circ} \mathrm{C}$ (Table 1). At high temperature, the cumulative pore volume decreased from $\sim 120$ to $\sim 100 \mathrm{~mm}^{3} \mathrm{~g}^{-1}$ for the PK3 series. PK4 presented $128.6 \mathrm{~mm}^{3} \mathrm{~g}^{-1}$, while PK5 $147.7 \mathrm{~mm}^{3} \mathrm{~g}^{-1}$ [8]. The reduction of the pore volume in the PK3 matrix is linked to the fact that the added kyanite was yet enough to hinder the formation of the glassy phase. In the PK4 and PK5 the evolution of the pore volume is 
Fig. 3 XRD patterns of the porous mullite matrix composite PK4 [8]

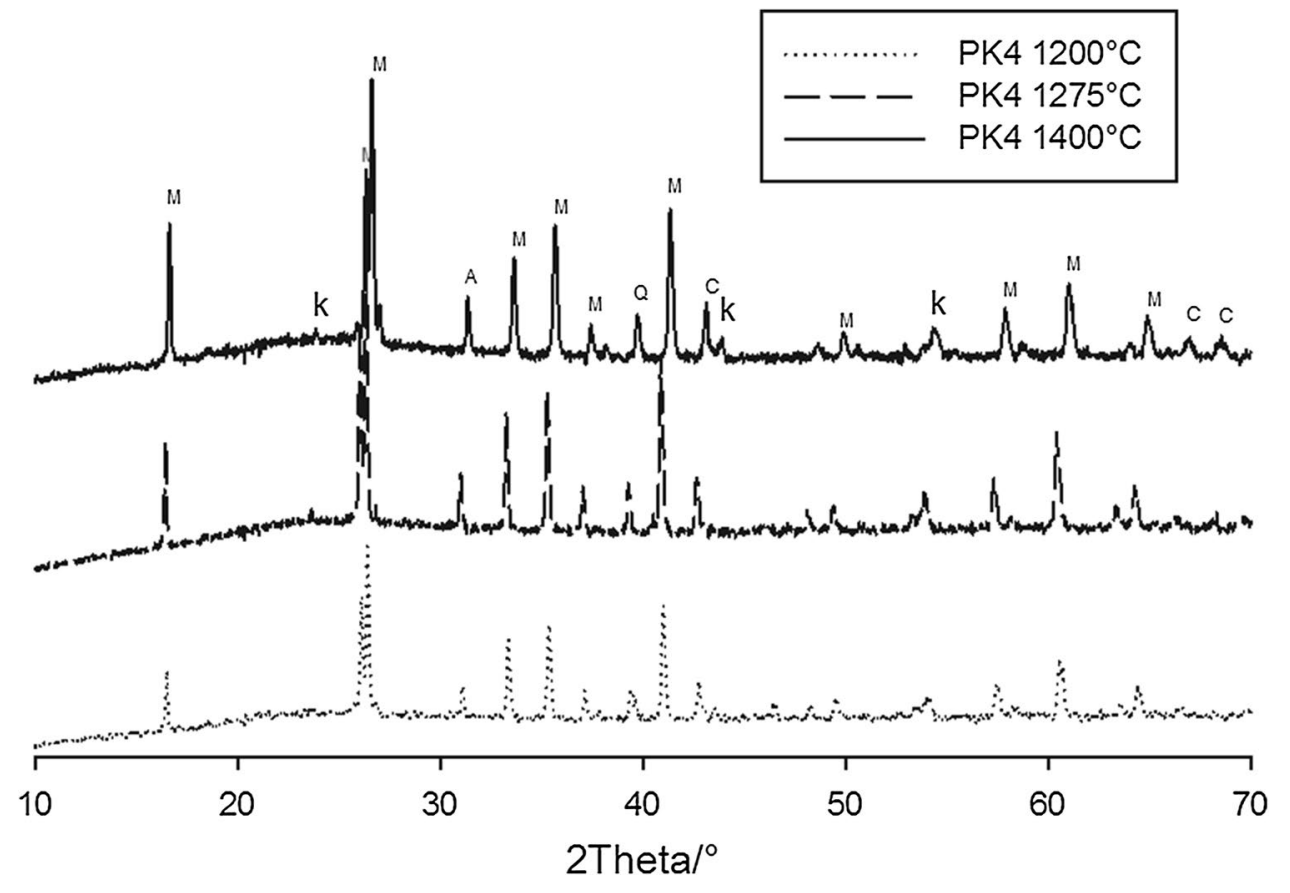

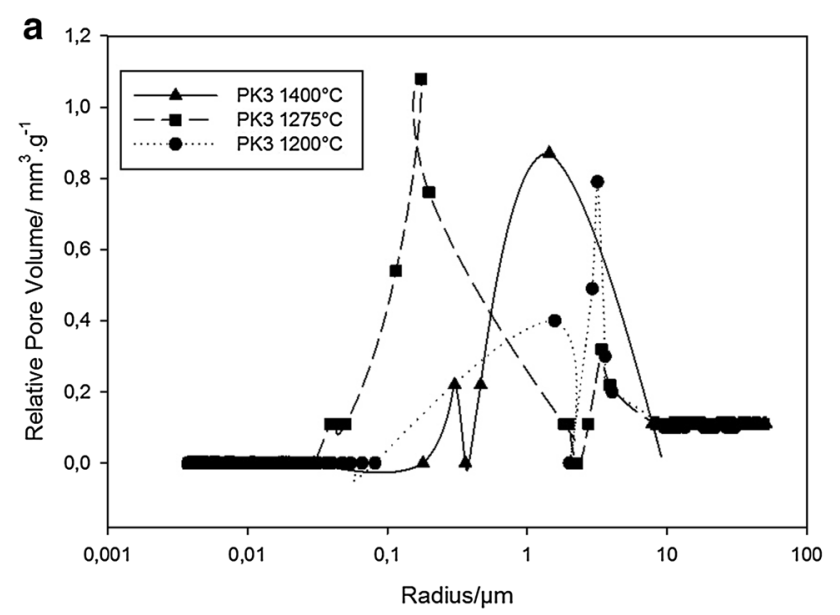
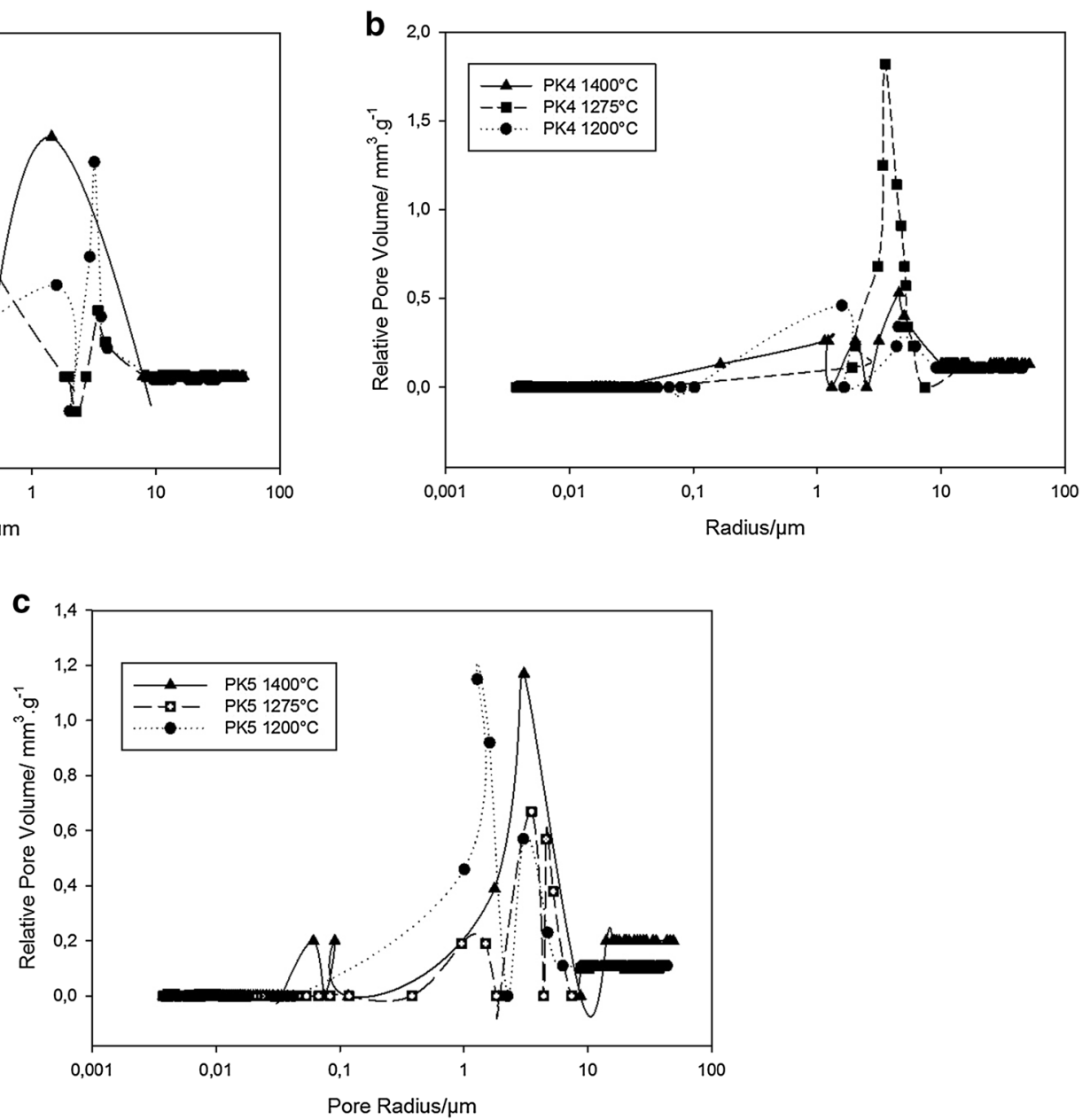

Fig. 4 Pores size distribution of the porous ceramic mullite composites: a PK3, b PK4 and c PK5 
Table 3 Variation of the average pore size and pore surface area of the fired samples with the kyanite content and temperature evolution

\begin{tabular}{|c|c|c|c|c|c|c|}
\hline \multirow{2}{*}{$\begin{array}{l}\text { Tempera- } \\
\text { ture }\left({ }^{\circ} \mathrm{C}\right)\end{array}$} & \multicolumn{2}{|l|}{ PK3 } & \multicolumn{2}{|l|}{ PK4 } & \multicolumn{2}{|l|}{ PK5 } \\
\hline & APR $(\mu \mathrm{m})$ & PSA $\left(m^{2} g^{-1}\right)$ & APR $(\mu \mathrm{m})$ & PSA $\left(m^{2} g^{-1}\right)$ & APR $(\mu \mathrm{m})$ & PSA $\left(m^{2} g^{-1}\right)$ \\
\hline 1200 & 3.2 & 0.9 & 4.4 & 0.5 & 3.5 & 0.4 \\
\hline 1275 & 3.5 & 1.25 & 4.2 & 1.0 & 4.5 & 0.8 \\
\hline 1350 & 2.1 & 1.4 & 1.6 & 8.5 & 2.0 & 2.0 \\
\hline 1400 & 3.4 & 0.7 & 3.3 & 2.0 & 3.8 & 4.0 \\
\hline
\end{tabular}

the results of the improvement in the crystallization and consequent reduction of the vitrified phases responsible for the reduction of the porosity, particularly the fine size of pores.

In fact, at $1200^{\circ} \mathrm{C}$, the pores size distribution shows a bimodal distribution with peaks centered at 1.7 and $3.4 \mu \mathrm{m}$ for PK3. The increase in the temperature shows a certain pore coarsening behavior at $1400^{\circ} \mathrm{C}$ (Fig. 4a). In PK4, there is a bimodal distribution at $1200^{\circ} \mathrm{C}$ with peaks at 1.6 and $4.4 \mu \mathrm{m}$ for the temperature of $1200^{\circ} \mathrm{C}$. The increase in the temperature up to $1275^{\circ} \mathrm{C}$ conducted to a unimodal distribution of pores with the peak centered at $3.4 \mu \mathrm{m}$. Increasing the temperature up to $1400^{\circ} \mathrm{C}$, three bands with peaks at 1.3, 4.1 and $4.5 \mu \mathrm{m}$ appeared as indications of the pores coarsening from the improvement in crystallization. The global behavior of the porous mullite-based matrices shows a less influence of the action of kyanite for relatively low temperature $\left(1200^{\circ} \mathrm{C}\right)$ due to the fact that at this level the decomposition of kyanite was not yet effective. The high temperature corresponds to more crystallization of mullite with additional pores bands. The reduction of the size of the first band can be attributed to the fact that the decomposition of kyanite produces acicular mullite as those from the transformation of metakaolin make more packing particles with consequence of the reduction of the intergranular pores size. In the absence of feldspar [19, 20], the pore size was between 2.4 and $9.5 \mu \mathrm{m}$. Results are in line with the pore network of sintered kyanite-based ceramics [8].

The porous mullite matrices as designed in the present work have nano- and micrometric pores that formed the pore network. The extension of crystallization with a significant reduction of the expression of the glassy phase allowed good percolation of the pores. At $1200^{\circ} \mathrm{C}$, with $37 \% \mathrm{wt}$. of the content of kyanite, the water permeability was $>500 \mathrm{~L} \mathrm{~m}^{-2} \mathrm{~h}^{-1} \mathrm{kPa}^{-1}$ for PK5 and increase with the reduction of the kyanite content ( $28 \% \mathrm{wt}$.) up to 750 $\mathrm{L} \mathrm{m}^{-2} \mathrm{~h}^{-1} \mathrm{kPa}^{-1}$ for PK3. This can be explained by the fact that kyanite is a stable and non-porous material at low temperature so its presence reduces the permeability as well as the pores connectivity of the matrix [8]. However, those grains of kyanite contributed to hinder the sintering and maintain at $1200^{\circ} \mathrm{C}$ the porous systems in comparison with conventional semi-vitrified matrix with lower porosity at that level of temperature [32]. The temperature development enhanced the crystallization of mullite; however, the balance with the reduction of the percolation probability seems to dominate all the matrices as the action of liquid phase even small as can be significant when considering semi-vitrified products. However, PK5 appeared as the matrix with the most connectivity of pores following by PK4 and PK3 [8]: in agreement with the kyanite content.

In the fully vitrified porcelain, open porosity is generally absent making the water absorption near zero [26, 33]. The closed porosity has pore size concentrated under $1 \mu \mathrm{m}$ with peaks between 0.01 and $0.1 \mu \mathrm{m}$ [3]. The bands of pores with size under $1 \mu \mathrm{m}$ in the porous mullite composites can be nucleated from the vitrified phases, while those with size between 3.4 and $4.5 \mu \mathrm{m}$ are intergranular pores characterizing the spaces between grains of mullite, the so-called intergranular pores. It was generally observed that the extension of crystallization was the main reason of the domination of this class of pores. The spaces generally filled by glassy phase in porcelain remain empty due to the limited expression of the vitrification. By the way as it can be appreciated with the cumulative pore volume curves [8], the connectivity of those matrices was significant in the range of the pore sizes between 1 and $10 \mu \mathrm{m}$.

\subsection{Relation porous microstructure: structural strength}

Figures 1 and 2 show the micrographs of resulting ceramic products sintered at $1200{ }^{\circ} \mathrm{C}$ and $1400{ }^{\circ} \mathrm{C}$, respectively. It consists of a typical vitrified matrix with homogeneous structure and dispersed fine pores tortuously interconnected. No significant differences can be identified among the three matrices sintered at low temperature $\left(1200{ }^{\circ} \mathrm{C}\right)$ : the total volume of pores having the same value of $\sim 100 \mathrm{~mm}^{3} \mathrm{~g}^{-1}$. At high magnification, PK3 seems to develop more connectivity of pores with respect to PK4 and PK5. It is also possible at this level to appreciate the viscoelasticity of the glassy phase present with respect to the conventional vitrified phase of porcelain: No microcracks have been identified as consequently of the quasiabsence of quartz grains which in the conventional 
porcelain formulations are the source of microcracks due to the thermal expansion mismatch. By the way the presence of micropores does not destabilized or altered the mechanical properties (flexural strength) that remained around $32.31+1.8 \mathrm{MPa}$ [8]. At $1400^{\circ} \mathrm{C}$ with low magnification, the micrographs showed matrices much similar to those at $1200{ }^{\circ} \mathrm{C}$. However, slight effects of the temperature on the viscoelasticity of the glassy phase do not affect the micrometric pores, but a little those nanometric can be observed at high magnification (Figs. 1d-f, $2 d-f$ ). In fact, the cumulative pore volume for the formulation PK3 was maintained at $\sim 100 \mathrm{~mm}^{3} \mathrm{~g}^{-1}$ independently of the temperature [8], but an increase in PK4 and PK5 specimens from 100 to $129 \mathrm{~mm}^{3} \mathrm{~g}^{-1}$ and $150 \mathrm{~mm}^{3} \mathrm{~g}^{-1}$ was noted, respectively. The difference is being linked to the significance of the crystalline/glassy phase ratio in the PK3, PK4 and PK5 from the ability of the crystallization that increases with the presence of kyanite. The decomposition and mullitization of kyanite produce essentially micrometrics pores from 0.9 to $9.4 \mu \mathrm{m}[9,34]$, and in this context of the semi-vitrified products, the maximum pores size was in the range 3-4 $\mu \mathrm{m}$ (Fig. 4). So high porosity is achieved although relatively low interconnectivity of nanometric pores with respect to the specimens at $1200^{\circ} \mathrm{C}$. Figure 5 illustrates the effects of the dominancy of the glassy phase at the relatively low amount of kyanite (PK3) and the particles packing in the case of more kyanite (PK5) that hinder the densification at $1400{ }^{\circ} \mathrm{C}$ (Fig. 5a, b).

The etching allowed to evidence the relatively low mullite content and glassier phase in PK3, while PK5 showed high concentration of acicular mullite together with secondary mullite. From the micrographs of Figs. 1, 2 and 5, it appeared that total transformation of kyanite to mullite happened at relatively few degrees before $1400^{\circ} \mathrm{C}$. Results are in line with the findings of Sainz et al. [31] that indicated the total transformation of the kyanite to mullite between 1350 and $1400{ }^{\circ} \mathrm{C}$. High temperature revealed rounded and platelet morphology for mullite from kyanite. The mix of acicular mullite, platelet and secondary elongated mullite can explain although microporous matrices's strength is achieved at $1400^{\circ} \mathrm{C}$ up to $79.9 \pm 1.12 \mathrm{MPa}$ (Figs. 6 and 7). The detailed study of the microstructure of the kyanite-based porcelain composites indicated the transformation of the metakaolin to acicular mullite. If this is largely described in the literature [24, 29, 35], fibrous mullite (Fig. 5b) aggregates, and one of the first stages of the transformation of kyanite to mullite is not common. At $1200{ }^{\circ} \mathrm{C}$, needle-like mullite grains were observed
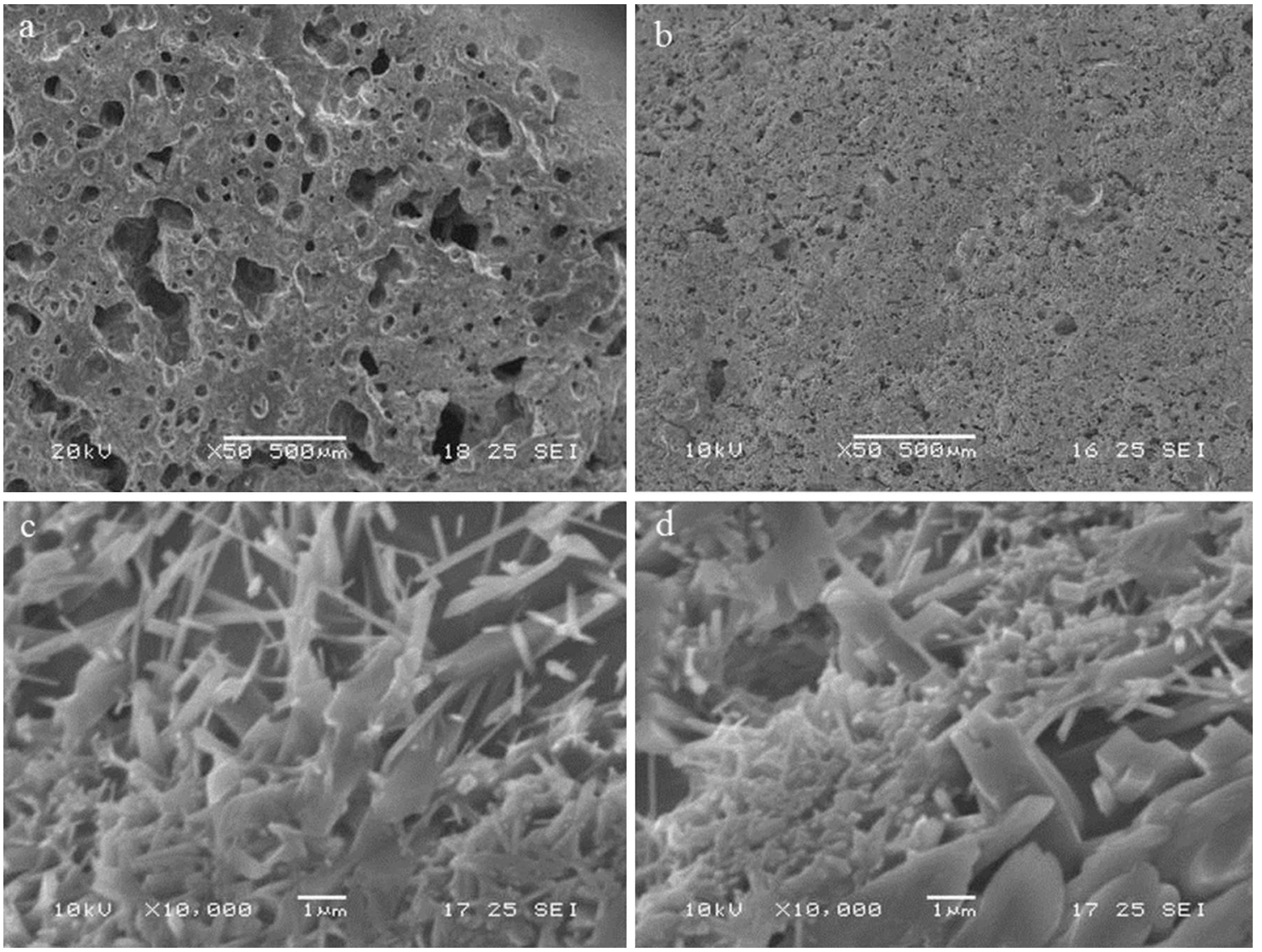

Fig. 5 SEM images of the etched samples after sintering at $1400^{\circ} \mathrm{C}: \mathbf{a}, \mathbf{c}$ PK3 and b, d PK5

SN Applied Sciences

A SPRINGER NATURE journal 

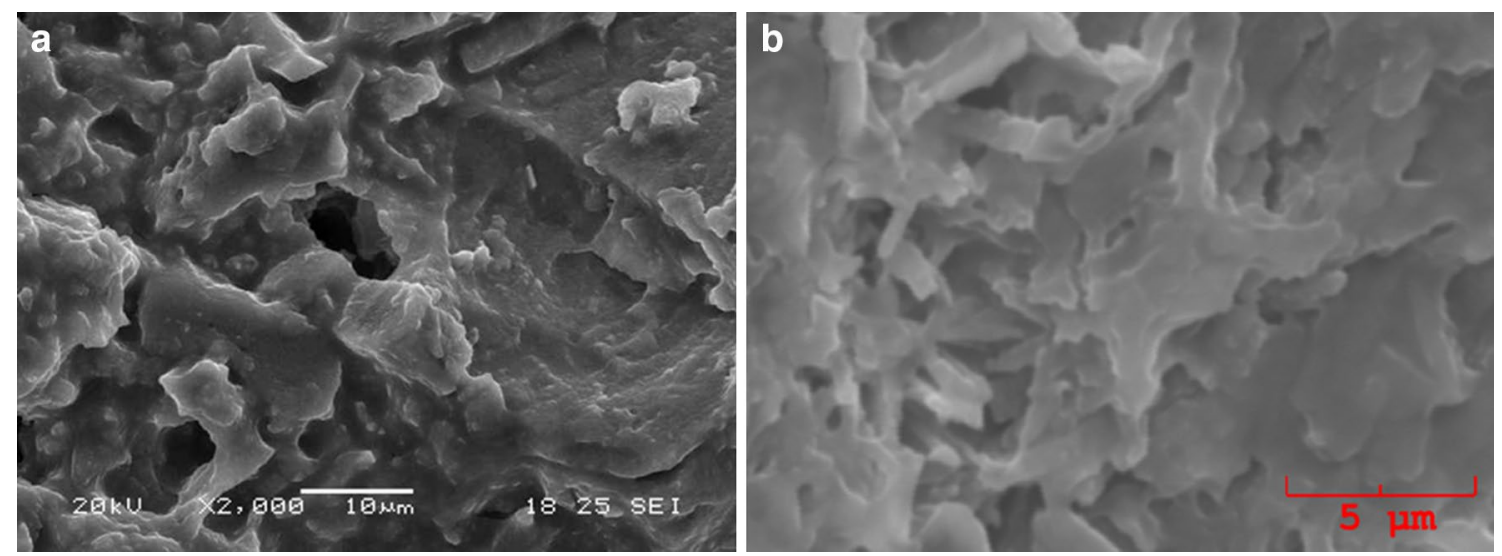

Fig. 6 Micrographs of PK3 showing the region with the mix of acicular mullite, platelet and secondary elongated mullite
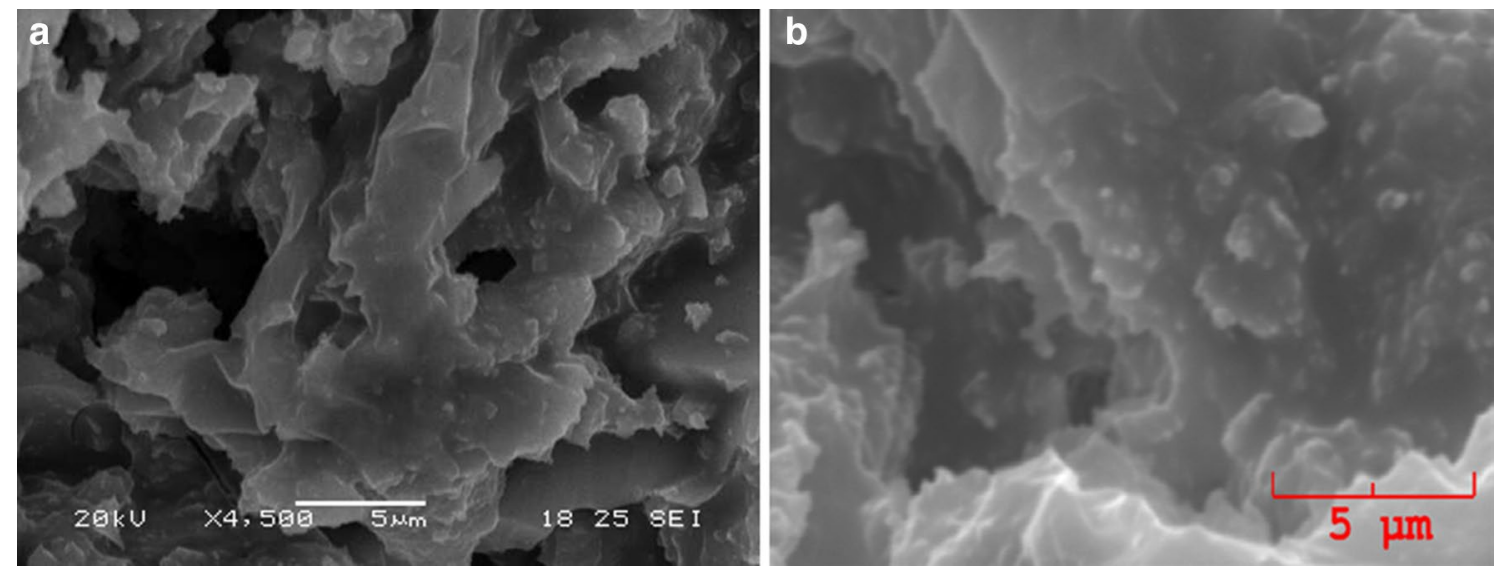

Fig. 7 Micrographs of PK5 showing the region with the mix of acicular mullite, platelet and secondary elongated mullite

on the surface of kyanite particles and the area close to the grain boundary. At temperature between 1200 and $1350^{\circ} \mathrm{C}$, the transformation always produces needle mullite grains showing orientation along the direction of elongation of the crystals. There were no appreciable changes in the grains size of mullite in the range of the temperature between 1200 and $1350^{\circ} \mathrm{C}$. At $1400^{\circ} \mathrm{C}$, higher temperature than $1350^{\circ} \mathrm{C}$ indicated by Sainz et al. [31] the morphology of the mullite grains was altered strongly and the crystals showed rectangular faces with rounded ends (Fig. 5).

The elastic modulus of the porous matrices was affected both with the kyanite content and with the temperature content (Fig. 8a, b). At $1200^{\circ} \mathrm{C}$, the increase in the kyanite content from 28 to $32 \mathrm{wt} \%$ increased the elastic modulus from 7 to $11 \mathrm{GPa}$ following with a drop to $9 \mathrm{GPa}$ when the kyanite content reached $38 \mathrm{wt} \%$. The increase in Young's modulus with the kyanite content was also observed at $1275^{\circ} \mathrm{C}$. At $1350^{\circ} \mathrm{C}$, the Young's modulus reached the value $>20 \mathrm{GPa}$ for $32 \mathrm{wt} \%$ of kyanite but decreased again with more kyanite content (38 wt\%). In fact, the specimen with the higher value of Young's modulus (PK4 at $1350^{\circ} \mathrm{C}$ ) is one with the lower porosity, presenting the lower main pore size (Table 3 ). As it can be observed in Table 3, the mean pore size for all the three formulations decreases between 1200 and $1350^{\circ} \mathrm{C}$ from 3.2 to $2.1 \mu \mathrm{m}$ for PK3; 4.4 to $1.5 \mu \mathrm{m}$ for PK4; and from 3.5 to $2.0 \mu \mathrm{m}$ for PK5. In the same range of temperature, the specific pore area increased and the PK4 showed the high surface area (Table 3). When the temperature reached $1400^{\circ} \mathrm{C}$, the pores size increased again for all the formulations, while the surface area dropped. It is then observed that the increase in the Young's modulus between 1200 and $1350{ }^{\circ} \mathrm{C}$ is evidentially linked to the increase in the mullite crystallization that explained the reduction of the mean pore size with consequent increase in the specific surface area. At $1400^{\circ} \mathrm{C}$, the reduction of the viscosity of the glassy phase affects the pore size through possible nucleation of additional pores from the glassy phase. 

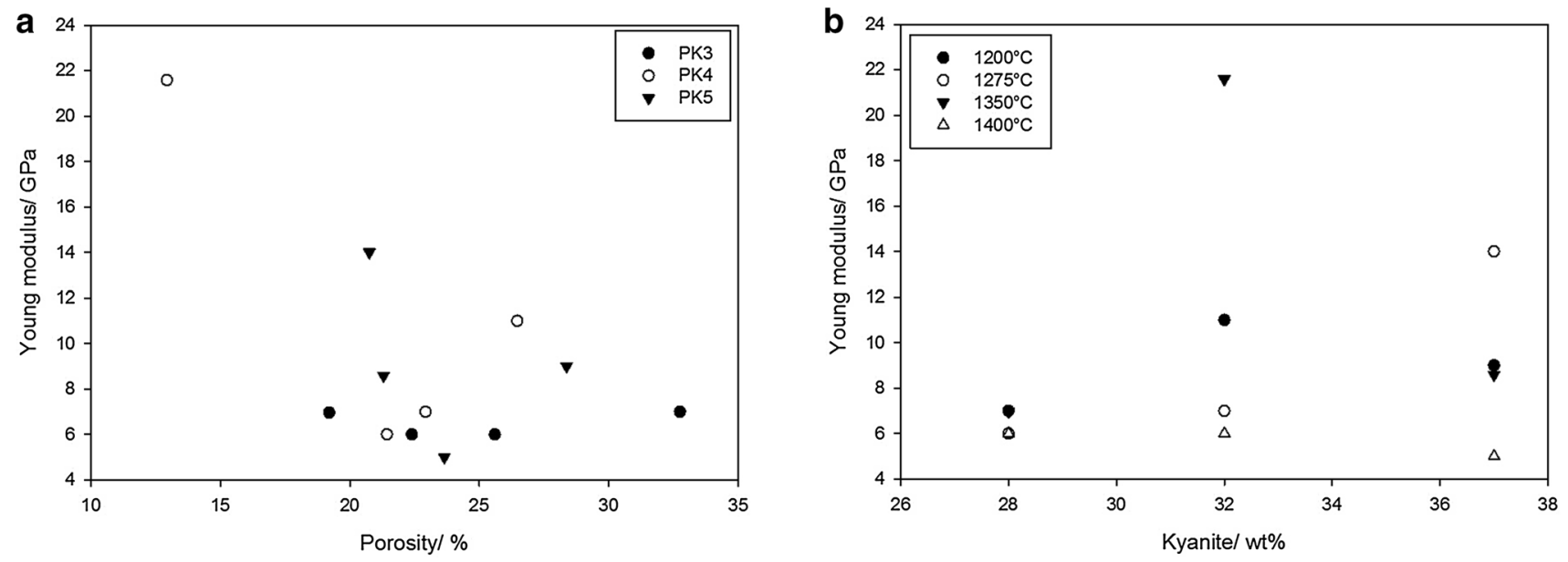

Fig. 8 Correlation of elastic modulus with the kyanite content (a) and porosity (b) for the matrices of PK3, PK4 and PK5 sintered between 1200 and $1400{ }^{\circ} \mathrm{C}$

\subsection{Discussion}

A suitable membrane support must provide high porosity and large pores size to decrease the resistance to the fluid flow [36-39]. Membranes for gas separation purposes need a support with low resistance to the filtrate flow and a smooth surface together with high strength and permeability. The porous mullite composites PK3, PK4 and PK5 offer characteristics in line with the above requirements. The final matrix is homogeneous enough to be considered as isotropic elastic and stress free as no microcracks were observed and the glassy phase was low and highly viscous to not induce expansion coefficient mismatch with the crystalline phase (Figs. 1, 2, 5, 6, 7). The pore size distribution of the porous semi-vitrified composites indicated pores band between 0.01 and $0.1 \mu \mathrm{m}(10-100 \mathrm{~nm})$ and between 1 and $10 \mu \mathrm{m}(1000-10,000 \mathrm{~nm})$ much similar to the pore distribution of zeolite $\mathrm{NaA}$ membranes supported on alumina hollow fibers described by Shao et al. [38]. Our solution to produce this class of materials is energy efficient, environmentally friendly with the use of low-cost natural mineral resources and relatively sustainable process and low-temperature processing compared to that of zeolite $\mathrm{NaA}$. The semi-vitrified porous matrices were designed using metakaolin, kyanite, $\mathrm{Al}_{2} \mathrm{O}_{3}$ from $\mathrm{Al}(\mathrm{OH})_{3}$ and potassium feldspar. While metakaolin is directly transformed to acicular mullite, feldspar and kyanite particles that are not ready to react in the range of the temperature of primary mullite formation $\left(950-980^{\circ} \mathrm{C}\right.$ ) act to hinder vitrification. Amorphous $\mathrm{SiO}_{2}$ from metakaolin can readily react with $\mathrm{Al}_{2} \mathrm{O}_{3}$. As from $1170^{\circ} \mathrm{C}$, the feldspar is decomposed producing amorphous silica that will bind to $\mathrm{Al}_{2} \mathrm{O}_{3}$ to form secondary mullite. In the main time kyanite starts to develop fibrous mullite as from $1200{ }^{\circ} \mathrm{C}$. The residual
$\mathrm{SiO}_{2}$ once again is going to form long grains of mullite II. The limitation of the growth of mullite from metakaolin and the production of the fine grains of acicular mullite from kyanite contributed to the densification of the interpores spaces and improved the flexural strength as well as the Young's modulus. As it can be observed in Table 3 and Fig. 4 , the mean pore size reduced with the increase in temperature up to $1350^{\circ} \mathrm{C}$. The pore network and their interconnectivity that can be controlled during the process offer a suitable possibility for the production of membrane supports for emerging engineering filtration particularly in the context where pressure resistance and mechanical strength are required.

\section{Conclusion}

Microporous mullite with multimodal pore size distribution was successfully designed avoiding extension of vitrification by using kyanite that acted to hinder vitrification at relatively low temperature and improve crystallization between 1200 and $1350^{\circ} \mathrm{C}$. Consequently, the semi-crystalline matrix maintained nano- and micrometric pores with good interconnection. In this range of temperature, optimum interconnectivity, lower average pore size $(1.54 \mu \mathrm{m})$, higher specific pore area and elastic modulus ( $>20 \mathrm{GPa}$ ) as the results of the control of the mullite grain growth and optimum densification and packing of acicular, fibrous and secondary mullite developed. At temperature above $1350^{\circ} \mathrm{C}$, the volume of nanometric pores reduced although there is microstructure coarsening. The final matrices combined porosity, pores connectivity and high strength promising for filtrations where mechanical strength and pressure resistance are required. 
Acknowledgements The authors acknowledge the staff of the Ceramics and Glass Laboratory of the University of Trento, Italy, for their assistance in the characterization of samples. They also recognize the assistance from MIPROMALO for the realization of this project.

\section{Compliance with ethical standards}

Conflict of interest The authors declare that they have no conflict of interest.

\section{References}

1. Iqbal Y, Lee WE (2000) Microstructural evolution in triaxial porcelain. J Am Ceram Soc 27:3121-3127

2. Iqbal Y, Lee WE (1999) Fired porcelain microstructures revisited. J Am Ceram Soc 82:3584-3590. https://doi. org/10.1111/j.1151-2916.1999.tb02282.x

3. Kamseu E, Bakop T, Djangang C, Melo UC, Hanuskova M, Leonelli C (2013) Porcelain stoneware with pegmatite and nepheline syenite solid solutions: pore size distribution and descriptive microstructure. J Eur Ceram Soc 33:2775-2784. https:// doi.org/10.1016/j.jeurceramsoc.2013.03.028

4. Bai CY, Li Y, Liu ZM, Liu PW, Deng XY, Li JB, Yang J (2015) Fabrication and properties of mullite-bonded porous SiC membrane supports using bauxite as aluminum source. Ceram Int 41:4391-4400. https://doi.org/10.1016/j.ceramint.2014.11.129

5. Lü Q, Dong X, Zhu Z, Dong Y (2014) Environment-oriented low-cost porous mullite ceramic membrane supports fabricated from coal gangue and bauxite. J Hazard Mater 273:136145. https://doi.org/10.1016/j.jhazmat.2014.03.026

6. Dong Y, Hampshire S, Zhou JE, Lin B, Ji Z, Zhang X, Meng G (2010) Recycling of fly ash for preparing porous mullite membrane supports with titania addition. J Hazard Mater 180:173180. https://doi.org/10.1016/j.jhazmat.2010.04.010

7. Hou Z, Cui B, Liu L, Liu Q (2016) Effect of the different additives on the fabrication of porous kaolin-based mullite ceramics. Ceram Int 42:17254-17258. https://doi.org/10.1016/j.ceram int.2016.08.020

8. Deutou NJG, Beda T, Biesuz M, Boubakar L, Melo UC, Kamseu E, Sglavo VM (2018) Design and characterization of porous mullite based semi-vitrified ceramics. Ceram Int 44:7939-7948. https://doi.org/10.1016/j.ceramint.2018.01.232

9. Guo H, Li W (2018) Effects of $\mathrm{Al}_{2} \mathrm{O}_{3}$ crystal types on morphologies, formation mechanisms of mullite and properties of porous mullite ceramics based on kyanite. J Eur Ceram Soc 38:679-686. https://doi.org/10.1016/j.jeurcerams oc.2017.09.003

10. Soboyejo WO, Akpan ET, Bashir IB, Zimba J, Hosannah N, Allameh $\mathrm{S}$ (2007) Effects of $\mathrm{Na}_{2} \mathrm{O}$ on the thermal shock resistance of aluminosilicate refractory ceramics. Mater Manuf Process 22:180-186. https://doi.org/10.1080/10426910601062248

11. Chen G, Ge X, Wang Y, Xing W, Guo Y (2015) Design and preparation of high permeability porous mullite support for membranes by in situ reaction. Ceram Int 41:8282-8287. https://doi. org/10.1016/j.ceramint.2015.02.045

12. Chang C, Ji Z, Liu C, Zhao F (2016) Permeability of filter cartridges used for natural gas filtration at high pressure. J Nat Gas Sci Eng 34:419-427. https://doi.org/10.1016/j.jngse.2016.07.015

13. Chen YF, Chang YH, Wang MC, Hon MH (2004) Effects of $\mathrm{Al}_{2} \mathrm{O}_{3}$ addition on the phases, flow characteristics and morphology of the porous kaolin ceramics. Mater Sci Eng A 373:221-228. https ://doi.org/10.1016/j.msea.2004.01.036
14. Xu L, Xi X, Shui A, Zhu W (2015) Preparation of mullite whisker skeleton porous ceramic. Ceram Int. https://doi.org/10.1016/j. ceramint.2015.04.097

15. Guo H, Li W, Ye F (2016) Preparation of microporous mullite ceramics by foaming for high temperature thermal isolation. Ceram Int 42:17332-17338. https://doi.org/10.1016/j.ceram int.2016.08.029

16. Guo H, Li W, Ye F (2016) Low-cost porous mullite ceramic membrane supports fabricated from kyanite by casting and reaction sintering. Ceram Int 42:4819-4826. https://doi. org/10.1016/j.ceramint.2015.11.167

17. Miao Z, Li N, Yan W (2014) Effect of sintering temperature on the phase composition and microstructure of anorthite-mullite-corundum porous ceramics. Ceram Int 40:15795-15799. https://doi.org/10.1016/j.ceramint.2014.07.105

18. Djangang CN, Tchamba AB, Kamseu E, Melo UC, Elimbi A, Ferrari AM, Leonelli $C$ (2014) Reaction sintering and microstructural evolution in metakaolin-metastable alumina composites. J Therm Anal Calorim 117:1035-1045. https://doi.org/10.1007/ s10973-014-3937-6

19. Kamseu CLE, Deutou NJG, Nzeukou NA, Melo UC, Magdalena LG, Sglavo VM, Beda T (2017) The role of kyanite in the crystallization and densification of the high strength mullite matrix composites. J Therm Anal Calorim. https://doi.org/10.1007/ s10973-017-6625-5

20. Deutou JGN, Mohamed H, Nzeukou NA, Kamseu E, Melo UC, Beda T, Leonelli C (2016) The role of kyanite in the improvement in the crystallization and densification of the high strength mullite matrix: phase evolution and sintering behaviour. J Therm Anal Calorim 126:1211-1222. https://doi. org/10.1007/s10973-016-5686-1

21. Washburn EW (1921) The dynamics of capillary flow. Phys Rev 17(3):273. https://doi.org/10.1103/PhysRev.17.273

22. Giesche H (2006) Mercury porosimetry: a general (practical) overview. Part Part Syst Charact 23:9-19. https://doi. org/10.1002/ppsc.200601009

23. ASTM C1161 (2003) Standard test method for flexural strength of advanced ceramics at ambient temperature. ASTM Int., West Conshohocken

24. Chen CY, Lan GS, Tuan WH (2000) Microstructural evolution of mullite during the sintering of kaolin powder compacts. Ceram Int 26:715-720. https://doi.org/10.1016/S0272 $-8842(00) 00009-2$

25. Olupot PW, Jonsson S, Byaruhanga JK (2010) Development and characterisation of triaxial electrical porcelains from Ugandan ceramic minerals. Ceram Int 36:1455-1461. https:// doi.org/10.1016/j.ceramint.2010.02.006

26. Lerdprom W, Chinnam RK, Jayaseelan DD, Lee WE (2016) Porcelain production by direct sintering. J Eur Ceram Soc 36:43194325. https://doi.org/10.1016/j.jeurceramsoc.2016.07.013

27. Lerdprom W, Zapata-Solvas E, Jayaseelan DD, Borrell A, Salvador MD, Lee WE (2017) Impact of microwave processing on porcelain microstructure. Ceram Int 43:13765-13771. https:// doi.org/10.1016/j.ceramint.2017.07.090

28. Wu J, Li K, Xu X, Zhang Y, Xu X, Lao X (2017) White porcelain material based on diopside. Int J Appl Ceram Technol 14:454460. https://doi.org/10.1111/ijac.12656

29. Wang $Y$, Liu $H$, Cheng $H$, Wang J (2014) Densification behavior and microstructure of mullite obtained from diphasic $\mathrm{Al}_{2} \mathrm{O}_{3}-\mathrm{SiO}_{2}$ gels. Ceram Int 40:12789-12796. https://doi. org/10.1016/j.ceramint.2014.04.133

30. Jiménez JA, Padilla I, Lõpez-Delgado A, Fillali L, Lõpez-Andrés $S$ (2015) Characterization of the aluminas formed during the thermal decomposition of boehmite by the rietveld refinement method. Int J Appl Ceram Technol 12:E178-E186. https ://doi.org/10.1111/ijac.12283 
31. Sainz MA, Serrano FJ, Bastida J, Caballero A (1997) Microstructural evolution and growth of crystallite size of mullite during thermal transformation of kyanite. J Eur Ceram Soc 17:12771284. https://doi.org/10.1016/s0955-2219(96)00231-2

32. Da Silva AL, Feltrin J, Dal Bó M, Bernardin AM, Hotza D (2014) Effect of reduction of thickness on microstructure and properties of porcelain stoneware tiles. Ceram Int 40:14693-14699. https://doi.org/10.1016/j.ceramint.2014.05.150

33. Mukhopadhyay TK, Ghatak S, Maiti HS (2009) Effect of pyrophyllite on the mullitization in triaxial porcelain system. Ceram Int 35:1493-1500. https://doi.org/10.1016/j.ceramint.2008.08.002

34. Kamseu E, Ngouloure ZNM, Ali BN, Zekeng S, Melo UC, Rossignol S, Leonelli C (2015) Cumulative pore volume, pore size distribution and phases percolation in porous inorganic polymer composites: relation microstructure and effective thermal conductivity. Energy Build 88:45-56. https://doi.org/10.1016/j. enbuild.2014.11.066

35. Chen G, Qi H, Xing W, Xu N (2008) Direct preparation of macroporous mullite supports for membranes by in situ reaction sintering. J Membr Sci 318:38-44. https://doi.org/10.1016/j. memsci.2008.01.034
36. Weyd M, Richter H, Puhlfürß P, Voigt I, Hamel C, Seidel-Morgenstern A (2008) Transport of binary water-ethanol mixtures through a multilayer hydrophobic zeolite membrane. J Membr Sci 307:239-248. https://doi.org/10.1016/j.memsci.2007.09.032

37. Biesheuvel PM, Verweij H (1999) Design of ceramic membrane supports: permeability, tensile strength and stress. J Membr Sci 156:141-152. https://doi.org/10.1016/s0376-7388(98)00335-4

38. Shao J, Zhan Z, Li J, Wang Z, Li K, Yan Y (2014) Zeolite NaA membranes supported on alumina hollow fibers: effect of support resistances on pervaporation performance. J Membr Sci 451:1017. https://doi.org/10.1016/j.memsci.2013.09.049

39. Wang Z, Ge Q, Shao J, Yan Y (2009) High performance zeolite LTA pervaporation membranes on ceramic hollow fibers by dipcoating-wiping seed deposition. J Am Chem Soc 131:6910-6911

Publisher's Note Springer Nature remains neutral with regard to jurisdictional claims in published maps and institutional affiliations. 